\title{
Environmental Improvement Drainage To Prevent Chikungunya Mosquito Nests In Rw 01 Kelurahan Nagasarari, Cipedes District, Tasikmalaya City
}

\author{
Indra Mahdi'), Empung1), Hendra1), dan Oka Agus Kurniawan Shavab',a), Albi \\ Muhammad Fauzi ${ }^{3)}$, Taufik Ibrahim ${ }^{3)}$, Suci Panatagama Setiawan ${ }^{3)}$ \\ ${ }^{1}$ Lecturer of Civil Engineering Department, Faculty of Engineering, Siliwangi University \\ ${ }^{2}$ Lecturer of History Education Department, FKIP Siliwangi University \\ ${ }^{3}$ Students of Civil Engineering Department, Faculty of Engineering, Siliwangi University \\ a) Corresponding Author: okaaks@unsil.ac.id
}

\begin{abstract}
The objectives of this service activity are as follows: 1). Increase public understanding of the dangers of chikungunya mosquitoes and their solutions, 2). They were suppressing the spread of chikungunya mosquitoes through fogging and implementing the recommendations for the Eradication of Mosquito Nests (PSN) in the surrounding environment, 3). They are creating a drainage prototype to prevent chikungunya mosquito nests which can be used as examples for making the next prototype, 4). Increase community participation in suppressing chikungunya mosquito nests through the construction of drainage channels, 5). Improve a clean culture in maintaining the cleanliness of the drainage in the surrounding environment. The planned activities to be carried out are in collaboration with the local health center, and the Tasikmalaya city health office to reduce the number of chikungunya mosquito nests and, together with the community, build good drainage channels. The method of activity used is by bringing in experts from puskesmas, health offices, and unsil academics. Next, an approach is taken in solving problems through the $5 \mathrm{~W} 1 \mathrm{H}$ strategy, which is solving problems from the questions: what, who, where, when, why, how. The solutions to the problems found in the field are as follows: 1). Provide a stimulus with the construction of a drainage system in accordance with the rules of the Public Works Department, 2). Cooperating with the Cigeureung Health Center by providing chemicals for fogging, 3). Counseling with the Health Center and the Tasikmalaya City Health Office regarding the dangers and solutions of diseases originating from chikungunya
\end{abstract}

Keywords: Drainage, Mosquito Nest, Chikungunya Mosquito

\section{INTRODUCTION}

Nowadays, there are many problems related to health, especially in Indonesia. Increased number of communicable diseases (re-emerging diseases), non-communicable diseases, and degenerative diseases. Infectious diseases are still the cause of the high morbidity and mortality of the Indonesian population. Efforts to eradicate and control infectious diseases often experience difficulties because of the many factors that influence the spread of these infectious diseases (Soedarto, 2009).

One of the infectious diseases that need attention is chikungunya, whose number of cases tends to increase, and its spread is wide and tends to cause outbreaks (Directorate General of P2PL, 2012). Chikungunya fever is relatively less dangerous and less fatal than DHF. Chikungunya fever is a self-limiting disease. However, the consequences of chikungunya fever are quite detrimental, and the patient can experience paralysis.

Paralysis in cases of chikungunya fever is only temporary as an effect of the viral breeding process in the blood, which causes feelings of pain in the bones and joints, making it difficult to move the limbs. Although it does not mean total paralysis, work productivity and daily activities practically stop (Amirullah et al., 2011). The location of the spread of this disease is not much different from DHF because the vector of the chikungunya virus is the Aedes mosquito and is commonly found in tropical and subtropical areas.

In the rainy season, the incidence of infection often occurs because the conditions are suitable for the development of mosquitoes. This causes an increase in the number of mosquito populations as virus vectors, thereby accelerating the spread of diseases found in rural and urban 
areas (Widiasih and Setyawan, 2012: 254). The spread of chikungunya disease cannot be separated from the influence of environmental conditions and behavior.

The environment is very influential on the existence of the chikungunya vector, especially the residential environment where a house is a place to live and to take shelter from climate disturbances and other outside disturbances. The natural environment, such as stagnant water, a dirty or unhealthy environment, and behaviors that do not practice $3 \mathrm{M}$ (draining, closing, and burying), greatly affect the breeding grounds for mosquitoes that spread chikungunya. Factors that play a role in the transmission of chikungunya disease, namely humans as hosts, viruses as disease agents, and Aedes aegypti and Aedes albopictus mosquitoes as intermediary vectors (Ministry of Health RI, 2012).

According to data from the World Health Organization (WHO), the results of the Extraordinary Events (KLB) of chikungunya in the world occurred in 2005 in India, Indonesia, Maldives, Myanmar, and Thailand, which reported three more than 1.9 million cases of chikungunya. In 2007 occurred in Europe with 197 cases. In November 2013, there were five proven cases of chikungunya with symptoms such as joint pain and weakness. On December 10, 2013, there were 20 cases of chikungunya infection (WHO, 2013). The incidence rate in Indonesia is very limited. Chikungunya fever was first reported in Samarinda in 1973. In subsequent reports, it occurred in Kuala Tungkal Jambi in 1980, and Mertapura, Ternate, and Yogyakarta in 1983. For almost 20 years (1983-2000), there were no reports of outbreaks of this disease. reports of outbreaks of chikungunya fever in Muara Enim, South Sumatra, and Aceh, were continued in Bogor, Bekasi, Purworejo, and Klaten in 2002. In 2004, an outbreak was reported that attacked 120 people in Semarang (Widoyono, 2008: 69). The number of cases of chikungunya fever in Indonesia decreased significantly in 2007 by 2,378 cases, and increased in 2008 by 3,592 cases, in 2009 by 83,756 cases, in 2010 by 52,703 cases, in 2011 by 2,998 cases, in 2012 amounted to 1,831 cases, but again increased significantly in 2013 amounted to 15,324 cases.

The incidence of community-based diseases from mosquitoes has turned out to be slightly forgotten with the occurrence of the COVID-19 Pandemic. This has made the eradication of other diseases forgotten, while in the community itself, the incidence of community-based diseases, especially mosquitoes, has increased, both chikungunya and dengue. This is indeed supported by the condition where people are now required by the government to stay at home and the existence of Large-Scale Social Restrictions, which ultimately part of the community's time is spent at home without doing activities. This poses a high risk because DHF and chikungunya mosquitoes are mosquitoes that like to be around. Indoors and the risk of being bitten increases.

A report from the Tasikmalaya City Health Office revealed that the incidence of mosquito-borne diseases increased significantly from 100 cases last year to 230 cases. According to the report, the area with the highest prevalence of the disease was the Nagarasari Village area, especially the Burujul RW 01 area. This was due to a large number of breeding places for mosquitoes or mosquito breeding places originating from drainage that did not flow perfectly, so there were puddles of water-used by mosquitoes for reproduction. The existence of this problem also provides encouragement from the service team to collaborate with partner 2, namely the Cigeureung Health Center, in order to provide solutions to the problems that are being experienced. The task of the puskesmas on this occasion is the provision of chemicals for fogging and counseling for the community in the form of films or the provision of Repellent.

Based on observations, the risk factors associated with chikungunya, according to Matelda (2010) are, the presence of larvae in an imperfect drainage system so that it becomes a breeding place for mosquitoes. Drainage has the meaning of draining, draining, dumping or diverting water. In general, drainage is defined as a series of water structures that function to reduce and/or remove excess water from an area or land so that the land can be used optimally. Drainage is also defined as an effort to control the quality of groundwater in relation to sanitation (Suripin: 2004).

Environmental and behavioral factors play an important role, especially in disease prevention efforts. In addition to eradicating mosquito nests, vector control efforts to prevent the incidence of chikungunya can be made by avoiding contact with adult mosquitoes by paying attention to community habits such as hanging clothes, using mosquito nets while sleeping, using mosquito 
repellent during the day, napping habits, burying things. Used, the habit of draining the bath, and geographical location and climate will indirectly affect the vector population that can cause chikungunya in an area.

\section{METHOD}

The implementation methods for this service activity are:

1. Provision of Materials by Experts

2. Focus Guidance Discussion (FGD)

3. Fogging

4. Making a good drainage prototype model

\section{RESULTS \\ Dangers and Disease Solutions from Chikungunya}

Presentation from the Community Health Center and the Health Service regarding the Dangers and Solutions of Chikungunya Disease

On October 10, 2020, this activity was attended by the village head of Nagarasari and the community of RW 01 Kelurahan Nagarasari, which consisted of representatives of PKK women, youth, and community leaders. The material presented is about the general description of the chikungunya mosquito, modes of transmission, signs and symptoms, treatment methods, management, and prevention methods.

Chikungunya comes from the Swahili language, which means "curved or curved body position." Refers to the patient's stooped posture due to severe joint pain (arthralgia). According to the Safety Data Sheet (MSDS) of the Canadian Office of Laboratory Safety, this joint pain mainly occurs in the knees, ankles, joints of the hands, and feet. Another opinion was expressed by Gould (2007) in Amirullah and Astuti (2011: 100) that chikungunya comes from the Makonde language, which means curved upwards, which refers to a stooped body due to arthritis symptoms of this disease.

Chikungunya is a type of dengue fever because the Aedes Aegyptus and albopictus mosquitoes transmit it. The difference is if the dengue virus attacks the blood vessels, while the Chikungunya virus attacks the joints and bones. There is no evidence to suggest that female mosquitoes transfer the Chikungunya virus to their eggs as the dengue virus is. In Chikungunya, there is also no severe bleeding, shock, or death, such as dengue fever. In the dengue virus, toxins will produce that attack blood vessels and cause death. While the virus that causes Chikungunya will produce a virus that attacks the bones.

Chikungunya disease is caused by a type of virus called the Chikungunya virus. This virus belongs to the family Togaviridae, genus alphavirus or "group A" anthropic borne viruses. The primary vector of transmission is Aedes Aegyptus. This virus can also be isolated from mosquitoes Aedes Africanus, Culex fatigans, Culex tritaeniorrhynchus, Aedes albopictus, and certain types of mosquito species in Africa also spread Chikungunya disease.

The Chikungunya virus was first isolated by Ross in 1953 since the dengue epidemic in Newala, Tanzania. Transmission of this disease is generally by mosquitoes of the genus Aedes. Geographical distribution covers sub-Saharan Africa, Asia, and North America (Diallo, et al.: 1999). Aedes sp mosquitoes can contain the Chikungunya virus when they bite humans experiencing viremia, two days before the fever until five days after the madness appears. Then the virus in the salivary glands multiplies within 8-10 days before it can be transmitted to humans at the next bite.

The chikungunya virus is known as an alphavirus. They are always spread by mosquitoes and are referred to as Arboviruses. This virus is the fifth group of the Togaviridae family. However, there are two more families, namely Astroviridae and Barnaviridae. Under the family Togaviridae, there are two more types of viruses, namely Alphavirus and Rubyvirus. Ross River Virus, Sindbis Virus, and Chikungunya Virus are viruses that belong to the Alphavirus group. 
Chikungunya transmission occurs when a transmitting mosquito bites a sick patient and bites another person. Apart from humans, other primates are thought to be a source of information. In addition, in the inhibitory hemagglutination test, mammals, mice, bats, and birds can also contain antibodies against the Chikungunya virus.

A person who has been infected with this disease cannot transmit the disease to others directly. The transmission process only applies to carrier mosquitoes. The incubation period for Chikungunya fever is between 1-7 days. Manifestations of the disease lasts from three to ten days.Symptoms associated with the chikungunya virus include the following:

a. Fever

Usually high fever, sudden onset accompanied by chills and flushed face. The madness of this disease is characterized by a high fever reaching 39-40 degrees C. Suddenly, the patient will experience a high fever for five days, so it is also known as a five-day fever

b. Joint Pain

Joint pain is a complaint that often appears before the onset of fever and can have severe manifestations so that sometimes the patient "feels paralyzed" before treatment. So some people call it bone fever or bone flu. The joints often complained of are the knees, wrists, toes and hands, and the spine.

c. Muscle Ache

Pain can be in all muscles or in the powers of the head and shoulder area. Sometimes there is swelling of the muscles around the ankles.

d. Red patches (rash) on the skin

These reddish patches occur on the first day of fever but are more common on days 4-5. The location is usually on the face, trunk, hands, and feet, especially the trunk and arms. Sometimes found bleeding in the gums.

e. Headache

Headache is a common complaint, conjunctival injection and a little photophobia

f. Seizures and loss of consciousness

Seizures are usually in children because the heat is too high, so not directly by the disease.

Amirullah and Astuti (2011: 100) added that the main symptom of being affected by Chikungunya, suddenly the body feels feverish, followed by rheumatic pain in the joints. There are typical symptoms, namely the emergence of aches, pains, and pain in the bones (bone fever/bone flu). In some cases, also found infected patients without causing symptoms at all (silent chikungunya virus). Paralysis can occur in cases of chikungunya fever even though it is only temporary as an effect of the viral breeding process in the blood, which causes feelings of pain in the bones and around the joints making it difficult to move the limbs. However, that does not mean complete paralysis.

There is no vaccine or specific medicine for Chikungunya. The course of this disease is generally quite good because it is a "self-limited disease," which will heal itself within a particular time. With adequate rest, fever medicine compresses, and anticipation of febrile seizures, this disease usually resolves itself within seven days. For sufferers, it is highly recommended to eat nutritious foods, sufficient carbohydrates, and especially protein to increase endurance and to drink as much water as possible to relieve symptoms of fever. Increase consumption of fresh fruit. Immune-boosting vitamins are also helpful for dealing with this disease because an excellent immune system and adequate rest can make joint pain disappear quickly. In patients who have been infected develop immunity/immunity to this disease in the long term. The treatment given is generally to eliminate or relieve existing clinical symptoms, such as administering heat medication, nausea/vomiting medication, or analgesics to relieve joint pain.

Presentation from the Community Service Implementation Team

This activity was carried out on October 10, 2020, attended by the village head of Nagarasari and the community of RW 01 Kelurahan Nagarasari, which consisted of representatives of PKK women, youth, and community leaders. The material presented is about the general description of the chikungunya mosquito, modes of transmission, signs and symptoms, treatment methods, management, and prevention methods. 
Drainage is one of the basics to meet the community's needs, which is the most critical component in a city's infrastructure planning. Fairizi (2015: 755) explains that the drainage system is a series of activities that form an effort to drain water, both surface water (runoff) and groundwater (underground water), from an area or area. Drainage aims to make a city's infrastructure safe, comfortable, clean, and healthy. Some other things are as follows:

1. To reduce excess water from an area or land so that the land can be used optimally.

2. As a surface water controller with actions to improve muddy areas, puddles/floods, and lower the groundwater level to an ideal level.

3. To improve the health of the residential environment.

4. Control of excess surface water can be carried out safely, smoothly, and efficiently and as far as possible can support environmental sustainability.

5. Can reduce/eliminate puddles of water that cause mosquito breeding for malaria and other diseases, such as dengue fever, dysentery, and other illnesses caused by an unhealthy residential environment.

Sinaga and Harahap (2016:42) add that the purpose of this drainage system is to keep roads from being flooded by rainwater for a long time (which will result in damage to road construction), but must be disposed of immediately through road drainage channels.

The poor drainage system harms the surrounding environment. The condition of the drainage channels that are flooded and some are even clogged, making the water unable to flow, this can be seen in front of houses or on the road. When it rains, the water overflows onto the streets of the alley. When it's not raining, the water pools black. This is what makes drainage prone to dengue hemorrhagic fever (DbD) mosquitoes. Clogged drainage conditions will be a source of disease, especially DHF mosquitoes where stagnant water is often used by Aedes aegypti mosquitoes to lay eggs. Such conditions make the larvae breed and grow into the Aedes aegypti mosquito, which carries the dengue hemorrhagic fever (DHF) outbreak

\section{Improvement of Environmental Drainage to Prevent Chikungunya Mosquito Nests in RW 01 Nagarasari Village, Cipedes District, Tasikmalaya City}

The following is a drainage planning flowchart for the service activities that we carry out:

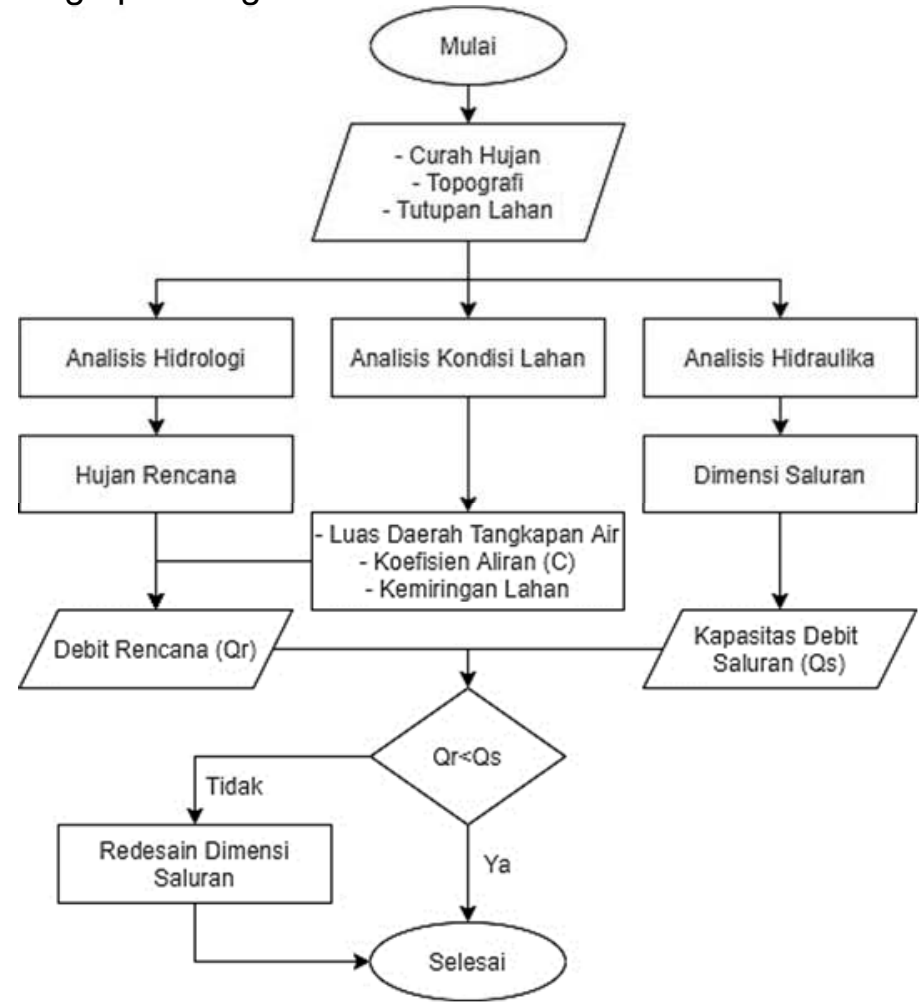

Figure 1. Drainage Channel Dimension Planning 
After the planning stage is made, measurements are made in advance based on the drainage conditions in the field. The following are the results of measurements in the field that have been carried out:

Table1. Field measurement results

\begin{tabular}{cccccccc} 
STA & TA $(\mathbf{m})$ & BA & BB & $\begin{array}{c}\text { B } \\
\mathbf{T}\end{array}$ & $\begin{array}{c}\text { Distance } \\
(\mathbf{m})\end{array}$ & $\begin{array}{c}\text { Height } \\
\text { Difference }\end{array}$ & ELV (+) m \\
\hline A & 1.18 & 13.5 & 11 & 12.25 & 25 & 0.04 & 100.4 \\
B & 1.26 & 13.55 & 10.5 & 12.025 & 30.5 & 0.0575 & 100.355 \\
C & 1.28 & 14.55 & 12.5 & 13.525 & 20.5 & 0.0725 & 100.2975 \\
D & 1.24 & 13.95 & 11.45 & 12.7 & 25 & 0.0 & 100.225 \\
E & 1.27 & 13.55 & 11.5 & 12.525 & 20.5 & 0.0175 & 100.195 \\
F & 1.26 & 14.95 & 12.5 & 13.725 & 24.5 & 0.1125 & 100.1775 \\
G & 1.24 & 14.7 & 12.5 & 13.6 & 22 & 0.1 & 100.065 \\
H & 1.24 & 15.5 & 12.55 & 14.025 & 29.5 & 0.1625 & 99.945 \\
I & 1.27 & 14.8 & 12.18 & 13.49 & 26.2 & 0.07 & 99.7825 \\
J & 1.27 & 12.5 & 9 & 10.75 & 35 & 0.19 & 99.7035 \\
K & 1.26 & 15.6 & 11.45 & 13.525 & 41.5 & 0.0925 & 99.5085 \\
\hline \multicolumn{7}{c}{ Total Distance $(\mathbf{m})$} &
\end{tabular}

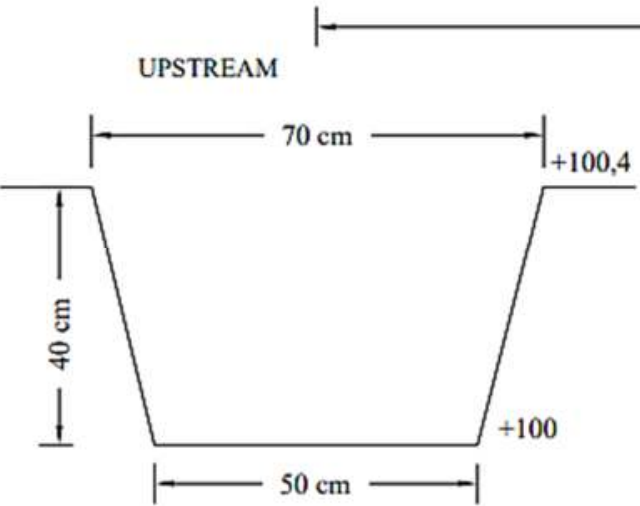
$300,2 \mathrm{~m}$

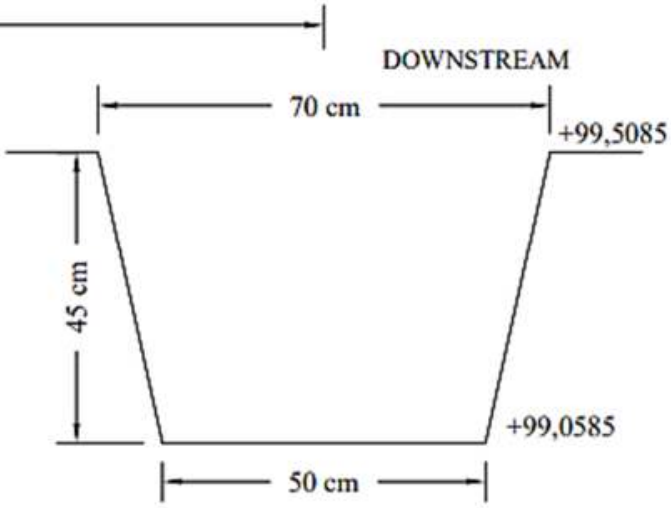

Figure 2. Cross-section of upstream and downstream channels

Condition of existing channel
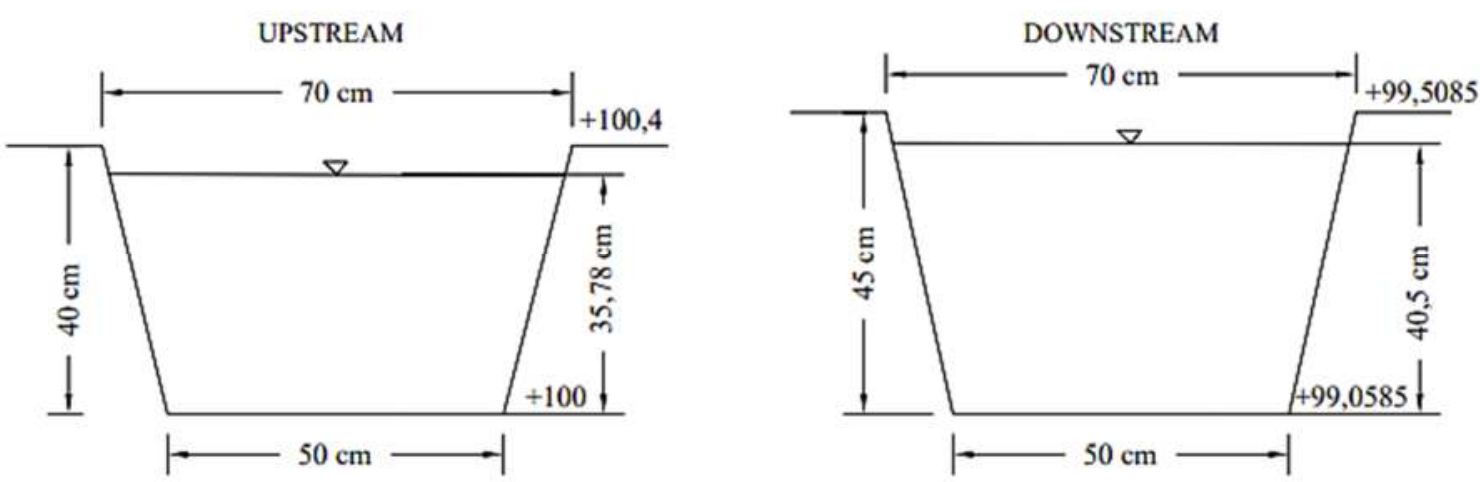

Figure 3. Upstream and Downstream conditions

Table 2. Condition of Existing Channel

Channel Length,

Channel Base Elevation,
$\mathrm{L}=300,2 \mathrm{~m}$
$\mathrm{e}_{1}=100,4$ 
Upstream channel dimensions,
$\mathrm{e}_{2}=99,0585$
$\mathrm{b}=50 \mathrm{~cm}$
$\mathrm{H}=40 \mathrm{~cm}$
$\mathrm{T}=70 \mathrm{~cm}$
$\mathrm{b}=50 \mathrm{~cm}$
$\mathrm{H}=45 \mathrm{~cm}$
$\mathrm{T}=70 \mathrm{~cm}$
$\mathrm{m}=0,2$
$\mathrm{n}=0,018$
$S=\left(e_{1}-e_{2}\right) / L * 100 \%$
$=0,004468$
$\mathrm{H}=\mathrm{W}+\mathrm{h}$
$\mathrm{H}=\sqrt{h / 2}+h$
$\mathrm{h}=35,78 \mathrm{~cm}$
$\mathrm{h}=40,5 \mathrm{~cm}$

Downstream channel dimensions,

Coefficient of roughness,

Slope,

Looking for the depth of the water level,

This is done until $\mathrm{h}$ is obtained that satisfies :

Upstream,

then the water level $(h)$ is obtained with the guard height $(W)$ for the upstream and downstream channels

\section{Formula used :}

Wet cross-sectional area,

Wet walking,

Hydraulic finger,

Flow Speed,

Water discharge,

Channel Upstream,

$\mathrm{A}=\mathrm{bh}+\mathrm{mh}^{2}$

$\mathrm{P}=b+2 h \sqrt{1+m^{2}}$

$\mathrm{R}=\mathrm{A} / \mathrm{P}$

$\mathrm{V}=\frac{1}{n} R^{2 / 3} S^{1 / 2}$

$\mathrm{Q}=\mathrm{V} \cdot \mathrm{A}$

$A=0,2045 \mathrm{~m}^{2}$

$P=1,2298 \mathrm{~m}$

$\mathrm{R}=0,1663 \mathrm{~m}$

$\mathrm{V}=0,0263 \mathrm{~m} / \mathrm{s}$

$Q=0,0054 \mathrm{~m}^{3} / \mathrm{s}$

Channel Downstream,
$A=0,2353 \mathrm{~m}^{2}$
$\mathrm{P}=1,326 \mathrm{~m}$
$\mathrm{R}=0,1774 \mathrm{~m}$
$\mathrm{V}=0,0275 \mathrm{~m} / \mathrm{s}$
$\mathrm{Q}=0,0065 \mathrm{~m}^{3} / \mathrm{s}$

Table 3. Capacity Addition

Addition of semicircular channel capacity with,

$$
\begin{aligned}
\mathrm{d}_{0} & =50 \mathrm{~cm} \\
\mathrm{y} & =1 / 2 \cdot \mathrm{d}_{0} \\
& =25 \mathrm{~cm} \\
\mathrm{e}_{1} & =100,4-0,25 \\
& =100,15 \\
\mathrm{e}_{2} & =99,0585-0,25 \\
& =98,8085 \\
\mathrm{~s} & =0,004468
\end{aligned}
$$

Channel base elevation,

Slope, 
Actual Height,

Looking for the depth of the water level,

This is done until $\mathrm{h}$ is obtained that satisfies,

then the water level $(h)$ is obtained with the guard height $(W)$

\section{Formula used :}

Trapezoid wet cross-sectional area,

Trapezoidal wet circumference,

The cross-sectional area of a semicircle,

Perimeter of a semicircle,

Hydraulic finger,

Flow Speed,

Water discharge,

Channel Trapezoid,

Channel Semi-circle,

$Q$ total $=Q$ Channel Trapezoid $+Q$ Channel Semi-circle Q

\section{Without guard height}

Channel Trapezoid,

Channel Semi-circle,

Q total = $Q$ Channel Trapezoid + Q Channel Semi-circle
$\mathrm{H}=70 \mathrm{~cm}$
$\mathrm{H}=\mathrm{W}+\mathrm{h}$
$\mathrm{H}=\sqrt{h / 2}+h$
$\mathrm{h}=64,32 \mathrm{~cm}$

$A=0,448$

$\mathrm{P}=1,9277$

$\mathrm{R}=0,2324$

$\mathrm{V}=0,0312$

$Q=0,014$

$A=0,0981$

$P=0,785$

$\mathrm{R}=0,125$

$\mathrm{V}=0,0206$

$\mathrm{Q}=0,002$

$=0,0160 \mathrm{~m}^{3} / \mathrm{s}$

Table 4. Flood Debit Control Plan

Area, (with $L=300,4 \mathrm{~m}$ and $\mathrm{b}=10 \mathrm{~m}$ )

Rain Intensity, (High density settlements and railroads)

Plan flood discharge,

Ideal conditions,

$\mathrm{V}$, (max speed requirement)
$\mathrm{A}=0,3 \mathrm{ha}$

$\mathrm{I}=200 \mathrm{~mm} / \mathrm{jam}$

$\mathrm{C}=0,7$

$\mathrm{Qr}=0,002778 \cdot \mathrm{C} \cdot \mathrm{I} \cdot \mathrm{A}$

$=0,116676 \mathrm{~m}^{3} / \mathrm{s}$

$\mathrm{V}=1,5 \mathrm{~m} / \mathrm{s}$ 
A total without guard height

$P$ total without guard height

Flow Speed,

Slope,

Water discharge max,

$$
\begin{aligned}
\mathrm{A} & =0,5461 \mathrm{~m}^{2} \\
\mathrm{P} & =2,7127 \mathrm{~m} \\
\mathrm{~V} & =\frac{1}{n} R^{2 / 3} S^{1 / 2} \\
\mathrm{~V} & =\frac{1}{n}(A / P)^{2 / 3} S^{1 / 2} \\
\mathrm{~S} & =0,006178 \\
\mathrm{Qmax} & =\mathrm{V} . \mathrm{A} \\
& =1,5 \times 0,5461 \\
& =0,81915 \mathrm{~m}^{3} / \mathrm{s}
\end{aligned}
$$

The modified dimensional capacity is safe against flood discharge with a speed according to the training $V \max =1.5 \mathrm{~m} / \mathrm{s}$ and $\operatorname{Qmax}>\operatorname{Qr}\left(0,116676 \mathrm{~m}^{3} / \mathrm{s}\right)$

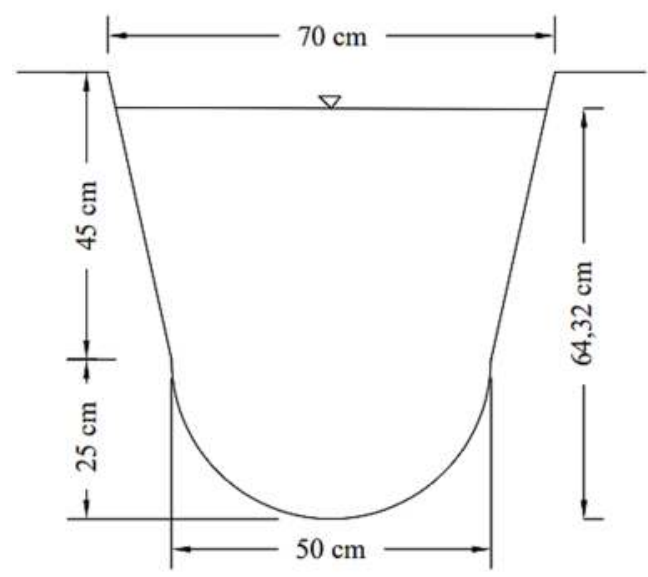

Figure 4. Modified channel appearance DISCUSSION

Based on the results of the analysis in the field, then a drainage prototype was made for the needs of community service activities in the context of preventing chikungunya mosquito nests in RW 01, Nagarasari Village, Cipedes District, Tasikmalaya City, as follows:

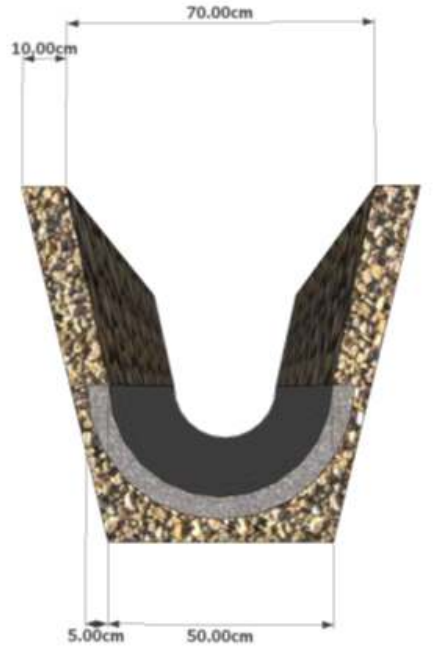

Figure 5. Prototype of drainage improvement to prevent Chikungunya mosquito nests As for the prototype model that has been made, then the drainage is made based on the model, which is as follows: 


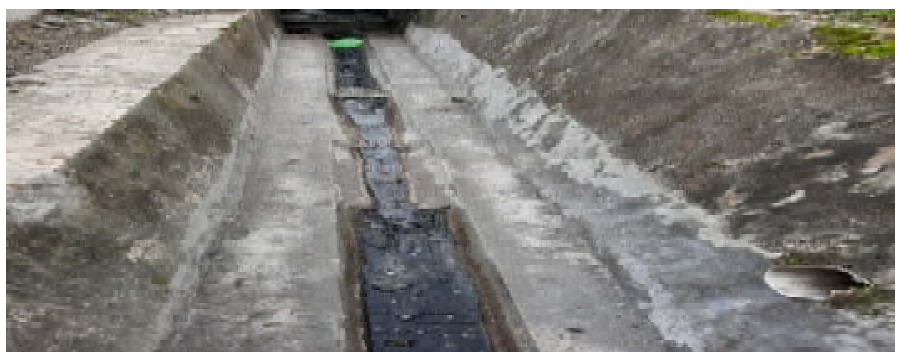

Figure 6. Implementation of drainage channel construction

The existence of this activity provides good benefits for the surrounding community. This is evidenced by the results of interviews with the Siliwangi university service team to the surrounding community. As stated by Aang that "This activity provides many benefits, such as we can find out what good drainage channels look like and it turns out that there are also many types of drainage channels." Another thing was expressed by Dadan that "This activity can embrace various groups, such as mothers, fathers, young people, puskesmas, RT, RW, Lurah and Tasikmalaya City Health Office. In addition, everyone joins in and supports all these activities for great benefits in the future." Fitri also added that "in the future, hopefully there will also be activities like this because there are so many things that have not been resolved by the residents due to lack of knowledge to solve existing problems." Furthermore, Didit added that "This activity made us think about resuming the drainage channel that was made, so that the channel becomes smooth and does not become a mosquito breeding ground. We will also maintain the conditions around the drainage channel so that it remains well maintained."

\section{CONCLUSION}

The following are conclusions that can be drawn:

1. The dimensions of the existing drainage channels are available, but they are less effective at functioning because they are covered with sediment, and the velocity is low.

2. Drainage channels based on real field data only drain a small discharge due to the small flow velocity.

3. The possible flood discharge is $0,116676 \mathrm{~m} 3 / \mathrm{sec}$. < channel capacity $0.81915 \mathrm{~m} 3 / \mathrm{s}$, with channel slope $S=0,006178$ and design speed $V=1.5 \mathrm{~m} / \mathrm{s}$ based on the modification results.

\section{RECOMMENDATIONS}

1. The existing channel is still capable of accommodating the discharge if there is no flood as long as the bottom sediment of the channel is dredged and the damaged ones are repaired.

2. The dimensions of the channel with the addition of a circle and a design speed of $1.5 \mathrm{~m} / \mathrm{s}$, and a slope of $S=0,006178$, have a large enough effect on the channel capacity.

\section{ACKNOWLEDGMENTS}

Praise and gratitude we pray to the presence of Allah Subhanahu Wa Ta'ala, because it is because of His mercy and grace that activities are carried out Community service can run smoothly. This community service can be carried out well with the support from (1) Head of LPPM PMP Siliwangi University (2) Nagarasari Village Head (3) All community members of RW 01 Nagarasari Subdistrict, Cipedes Subdistrict (4) Cigeureung Health Center, and (5) Tasikmalaya City Health Office and (6) Undergraduate student of Civil Engineering Department, Faculty of Engineering, University Siliwangi. May Allah Subhanahu Wa Ta'ala repay all the good that has been done. Amen.

\section{REFERENCES}

Amirullah, dan Astuti EP, (2011), Chikungunya: Transmisi dan Permasalahannya, Aspirator, 2(3), 100-106.

Diallo, M., Jocelyn, T., Moumouni, T.L., and Didier, F, (1999), Vectors of

Chikungunya Virus in Senegal : Current Data and Transmission Cycles. Am. J. Trop. Med. Hyg., 60(2), 1999, pp. 281-286 
Widiasih, D., A., dan Setyawan, (2012), Epidemiologi Zoonosis di Indonesia, Yogyakarta, Gadjah Mada University Press.

Fairizi, Dimitri, (2015), Analisis dan Evaluasi Salran Drainase Pada Kawasan Perumnas Talang Kelapa di Subdas Lambidaro Kota Palembang, Jurusan Teknik Sipil dan Lingkungan (JTSL), Volume 3 (1), 755-765.

Kementrian Kesehatan Republik Indonesia, (2012), Pedoman Pengendalian Penyakit Chikungunya 2012 : Direktorat Jenderal Pengendalian Penyakit dan Penyehatan Lingkungan Kementrian Kesehatan RI, Profil Kesehatan Indonesia, Jakarta

Kemenkes RI. Kementrian Kesehatan RI, 2011, Penyehatan Udara Dalam Ruang Rumah, Jakarta, Kemenkes RI.

Matelda, Rumatora. 2010. Faktor-Faktor Yang Berhubungan Dengan KasusChikungunya Pada Kejadian Luar Biasa (Klb) Di Dusun Mentubang Desa Harapan Mulia Kabupaten Kayong Utara, Tesis Fakultas Kesehatan Masyarakat Universitas Indonesia, Depok.

Sinaga, R., M., dan Harahap, R., (2016), Analisis Sistem Saluran Drainase Pada Jalan Perjuangan Medan, Jurnal Education Building, 2 (2), 41-49.

Soedarto, (2009), Penyakit Menular di Indonesia, Jakarta, CV Sagung Seto.

Suripin, (2004), Darinase Perkotaan, Jakarta, Erlangga.

Widoyono, (2008), Penyakit Tropis, Epidemiologi, Penularan, Pencegahan dan Pemberantasannya, Jakarta, Erlangga. 